\title{
The Effect of Government Involvement on Chinese Firms' Corporate Entrepreneurial Activities:
}

\author{
The Case of Chinese Automobile Industry
}

\author{
Grace Chun Guo \\ Crystal X. Jiang \\ Qin Yang
}

\begin{abstract}
In recent decades many emerging markets (EMFs) have undertaken entrepreneurial transformations to adapt to institutional transition and industrial change. Corporate entrepreneurship (CE) provided EMFs viable ways to revitalize, reconfigure, and transform successfully with the dynamic environment. Although previous research examined government roles on EMFs' CE activities, little is known about the mechanisms of how government exerts influence on CE activities. To fully understand CE of EMFs, we propose a stage model to explore specific roles governments play that affect CE activities over time. In particular, we investigate how governments' grabbing hand, helping hand, and invisible hand roles affected Chinese auto firms' CE activities at different stages from 1980 to 2016. Government involvement is summarized and the advantages and disadvantages of these roles are analyzed.
\end{abstract}

Keywords: corporate entrepreneurship; government roles; innovation; venturing; emerging market; Chinese automobile industry

Existing research has extensively examined how emerging market firms (EMFs) have grown and become important players in world business (e.g., Jiang et al., 2016; Kotabe, Jiang, and Murray, 2017; Li and Kozhikode, 2008; Mathews, 2006). In particular, EMFs have undertaken entrepreneurial transformations to adapt to institutional transition and industrial change (Yiu and Lau, 2008). Corporate entrepreneurship (CE) provided EMFs viable ways to revitalize, reconfigure, and transform successfully with external environment (e.g., Zahra, Ireland, Gutierrez, and Hitt, 2000). CE activities such as innovation, strategic renewal, and corporate venturing (Covin and Slevin, 1991) are critical for EMFs to venture internationally (Wang, Hong, Kafourors, and Wright, 2012; Yiu, Lau, and Bruton, 2007) and gain competitive advantages in fierce domestic and global competition.
A firm's ability to engage in CE is not only determined by its available resources (Covin and Slevin, 1991) and dynamic capabilities (Zahra and George, 2002), but also by its embedded institutional environments. Institutional environments can influence firms' strategic activities (Kotabe et al., 2017) and can shape the nature and level of innovation in a country (Busenitz, Gomez, and Spencer, 2000). Among institutional forces, government plays important roles in fostering entrepreneurial activities (Minniti, 2008) through initiating policies, providing support, and regulating industrial development (Kotabe et al., 2017).

EMFs differ from their counterparts in developed countries in their lack of valuable resources and capabilities (Yiu and Lau, 2008). To address their resources insufficiency, EMFs are found to rely on preferential treatment from the government to achieve business success (Luo, 2000). Governments could be involved in providing entrepreneurial opportunities for EMFs to access valuable resources and to enhance firm capabilities. As such, there are notable differences between EMFs and developed market firms (DMFs) in conducting CE activities (Kotabe et al., 2017).

Although previous research examined that the fundamental question of whether government policies have positive effect on entrepreneurial activities (Minniti, 2008), little is known about how governments matter in EMFs'CE activities. Drawing on previous models (Frye and Shleifer's 1997; Shleifer and Vishny, 2002) of governments' roles, we propose the following two research questions to examine government's involvement in promoting CE activities in transition economies. First, what roles do governments play in enabling and stimulating firms' $\mathrm{CE}$ in emerging economies? Second, what is the impact of government involvement on important CE outcomes, namely EMFs' innovation, strategic renewal, and corporate venturing? We adopted a case study approach (Eisenhardt, 1989; Yin, 1994) to our inquiry. We chose the automobile industry in China as our research context because China

6 NEW ENGLAND JOURNAL OF ENTREPRENEURSHIP 
has become the world's largest and fastest-growing emerging economy and its automobile industry has been the largest in the world measured by unit production since 2008. Under the strong influence of the government, most Chinese automobile enterprises have undergone an entrepreneurial transformation in order to compete locally and globally, especially after China's entry into the World Trade Organization (Peng, 2003; Tan, 2007).

In this article, we provide a literature review of CE and describe government's roles in transition economies based on Frye and Shleifer's (1997) and Shleifer and Vishny (2002). We then analyze Chinese government's involvement and roles in the development of the automobile industry and the CE activities of auto companies between the early 1980s to 2016. Lastly, we discuss outcomes of the Chinese government's involvement and provide implications for theory and practice.

\section{Theoretical Background Corporate Entrepreneurship (CE)}

CE is defined in various ways in the entrepreneurship research. CE was viewed as the rebirth of organization through a renewal (Guth and Ginsberg, 1990). Zahra (1995, 1996) defines CE as a process of creating new businesses or the strategic renewal of an existing business to improve profitability and competitive advantages. CE requires firms to engage in three distinct but related activities: innovation, strategic renewal, and cooperate venturing (Zahra, 1996). First, innovation requires firms to develop cultures, processes, and structures to support continuous new product launches in its current markets as well as introduce existing products into new markets (Covin and Miles, 1999).

Second, CE also embodies renewal activities that enhance an enterprise's ability to compete and take risks, with or without the creation of new businesses. Strategic renewal refers to the "revitalization of the company's operations by changing the scope of its business, its competitive approach, or both" (Zahra, 1996: 1715). These renewal activities may include opportunity identification and exploitation as well as creating and sustaining a competitive advantage through strategic renewal and business model reconstruction. It can also include organizational rejuvenation-a firm's ability to improve its internal processes, structures, and capabilities, to better execute strategies and often involves administrative innovations in human resource management (Covin and Miles, 1999). Lastly, strategic renewal may also involve domain redefinition-activities involving the creation of new product market position that competitors have not recognized or exploited (Covin and Miles, 1999). According to Covin and Miles (1999), the focus of domain redefinition is exploring for what is possible rather than exploiting what is currently available.

Third, corporate venturing refers to activities that "seek to generate new businesses for the corporation in which it resides through the establishment of external or internal corporate ventures" (Von Hippel, 1977: 163). Corporate venturing can be divided into internal and external venturing (Phan, Wright, Ucbasaran, and Tan, 2009). Internal corporate venturing involves the creation of new businesses that reside within the corporate structure and preexisting organization structures may accommodate these new ventures or newly created organizational entities. External corporate venturing involves investing in young, early growth-stage businesses created by external parties through corporate venture capital, licensing, acquisitions, and joint ventures.

In short, CE requires organizations to engage in activities that continuously extend their domain of competence and respond to risks and opportunities through resource configuration and capability development to meet changing customer demands and competitor strategies (Guo et al., 2014). However, CE activities do not occur in a vacuum and are under the influence of institutional environments. National culture (Hayton, George, and Zahra, 2002), accepted industry norms and rules of engagement in competition (Covin and Miles, 1999), and public policies as well as government involvement (Wang et al., 2012) can exert strong influence on firms' ability and willingness to engage in CE activities. Among institutional forces, government plays important roles in fostering entrepreneurial activities (Minniti, 2008). This is especially the case for firms in emerging economies where institutional mechanisms are found to complement firms' activities (Kotabe et al., 2017) when their markets have not reached the technological frontier (Mahmood and Rufin, 2005) and EMFs have not fully developed their competitive advantages to compete with their counterparts from developed countries (Kotabe et al., 2017).

The following section introduces the stage models of government roles in transition economies based on Shleifer and Vishny (2002) and provides an analysis of government's involvement in and impact on CE activities and industry development of the Chinese automobile industry from the early 1980s to 2016. 


\section{Government Roles and Institutional Influence}

According to Shleifer and Vishny (2002), the impact of governments on entrepreneurial activities in transition economies can be described as the invisible hand, the helping hand, and the grabbing hand models. Under the invisible hand model, government restricts itself to providing basic public goods, such as contract enforcement, law and order, and some regulations. Governments adopting invisible hands are generally well organized, benevolent, and refrain from making allocative decisions. Under the helping hand model, government is actively involved in promoting economic activities, establishing industry policies, and often has close ties to entrepreneurs. In this model, government has strong arbitrative power and leaves little room for the legal framework. Lastly under the grabbing hand model, government is considered interventionists; it remains largely independent of courses and is empowered to impose a variety of regulations on businesses.

An institution-based view suggests that firms' strategic choices are the outcome of the interaction between organizations and institutions. While industry conditions, firm resources, and capabilities can drive strategic choices, formal and informal constraints of a particular institutional environment can also exert strong influence. Based on Kostova's (1997) three-dimensional institutional profile, a country's level of entrepreneurship is determined by government policies (regulatory dimension), shared knowledge to establish new business (cognitive dimension), and value system (normative dimension). Although government's influence on entrepreneurial activities is mainly through public policies and regulations, or coercive isomorphism in DiMaggio and Powell's (1983) term, we speculate that governments, especially those in transition economies, can also shape the value system by imposing normative isomorphism (DiMaggio and Powell, 1983), which requires firms to abide by the norms or rules established by the government for a specific profession or industry. In addition, it is possible that governments in transition economies, to address their political goals, can play an active role in issuing favorable policies and allocating resources to help construct a shared knowledge base for firms to engage in entrepreneurial activities. In the next section, we apply Frye and Shleifer (1997)'s framework and provide an analysis of the Chinese government's involvement and institutional influence in reshaping the automobile industry.

\section{Chinese Automobile Industry and Government Involvement}

Governments of a few major emerging economies, including Brazil, India, and China, have successfully developed a viable national automotive industry as one of the national economic pillars (Sturgeon and Van Biesebroeck, 2010). Even in these countries, however, local automobile firms are still relatively weak, and multinational firms will continue to dominate the domestic industry for a long time (Chang, 2016; Guo, et al., 2014). The difficulty of developing competitive automobile enterprises in emerging economies is attributed to unique institutional factors (e.g., heavy government regulations and interventions in the automotive industry), an underdeveloped supplier industry, underdeveloped intellectual property rights (IPR) environment (Jiang, et al., 2011), and price-sensitive domestic markets (Guo, et al. 2014)

The case of the Chinse automobile industry follows the general development trajectory experienced by those in other emerging economies. China surpassed the United States in production of vehicles in 2008 (Guo, et al., 2014), and the Chinese government succeeded in creating the world's largest automobile market with 24.5 million units in 2015 (Chang, 2016). From 2000 to 2015, China's market share of auto production sextupled. In particular, the market share at the worldwide auto production almost doubled from 12 percent in 2007 to 23 percent in 2010 (Quest Trend Magazine). The two graphs in Figure 1 illustrate the growth trend of China's auto industry.

\section{Initiation Stage (Early 1980s to Late 1990s)}

In the early 1980s, recognizing the lack of capital and technological expertise of the local automobile makers, Chinese political leaders established the country's passenger car production and an automotive supply chain. In 1985, the government named the automobile industry as one of its "pillar" industries (Roberto, Guo, and Jiang, 2011). To achieve these goals, the government encouraged foreign direct investment and established laws that forced international automakers into joint venture (JV) arrangements. In 1994, the government developed the China Automotive Industry Policy, which, for the first time, set clear 50-50 JV requirements between Chinese automakers and their foreign partners. To encourage foreign direct investment (FDI), the government provided favorable policies, such as a two-year tax exemption and a three-year tax reduction for Sino-foreign firms.

8 NEW ENGLAND JOURNAL OF ENTREPRENEURSHIP 
Figure 1. Growth Trend of China's Auto Industry.
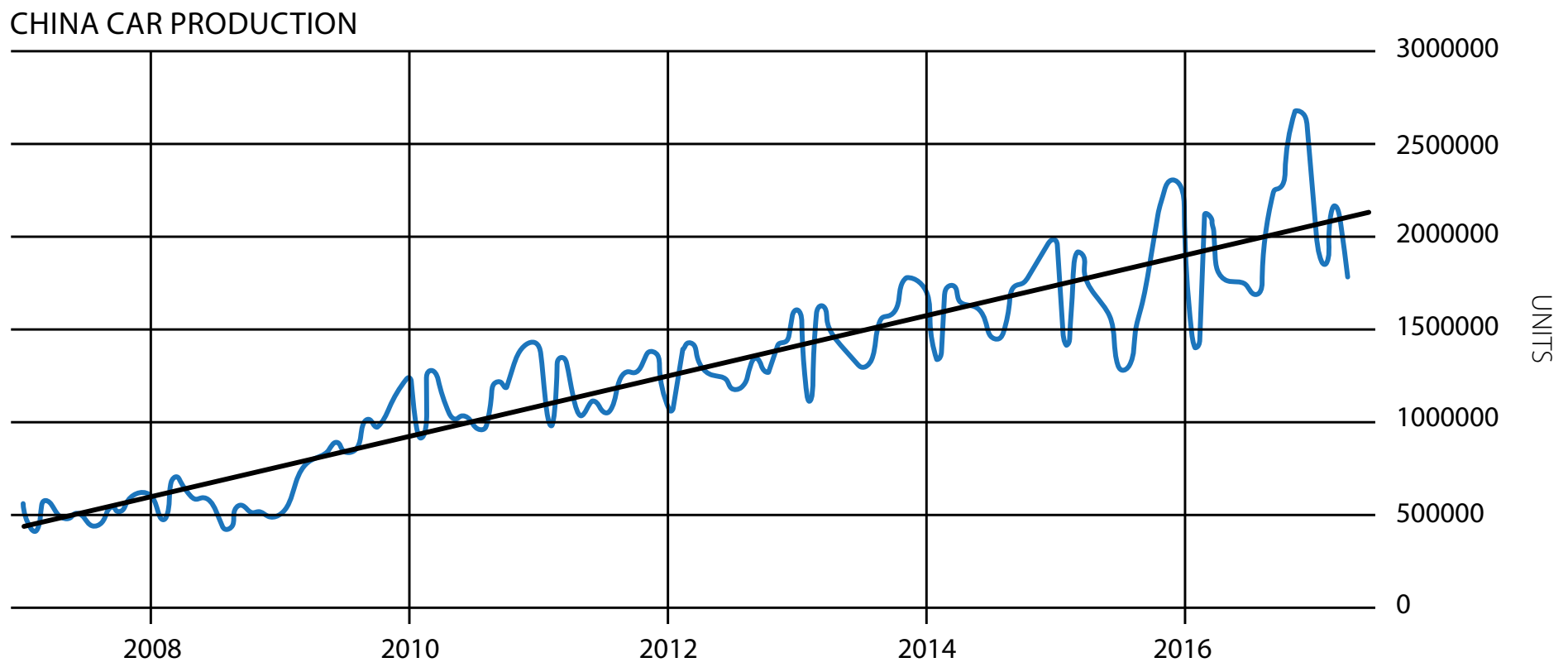

Source: www.tradingeconomics.com | CAAM - China Association of Automobile Manufacturers

\section{Global auto production grows by 50\%, China's share by sixfold since 2000}

Index global auto production and China's share 2000-2015 $(2010=100)$

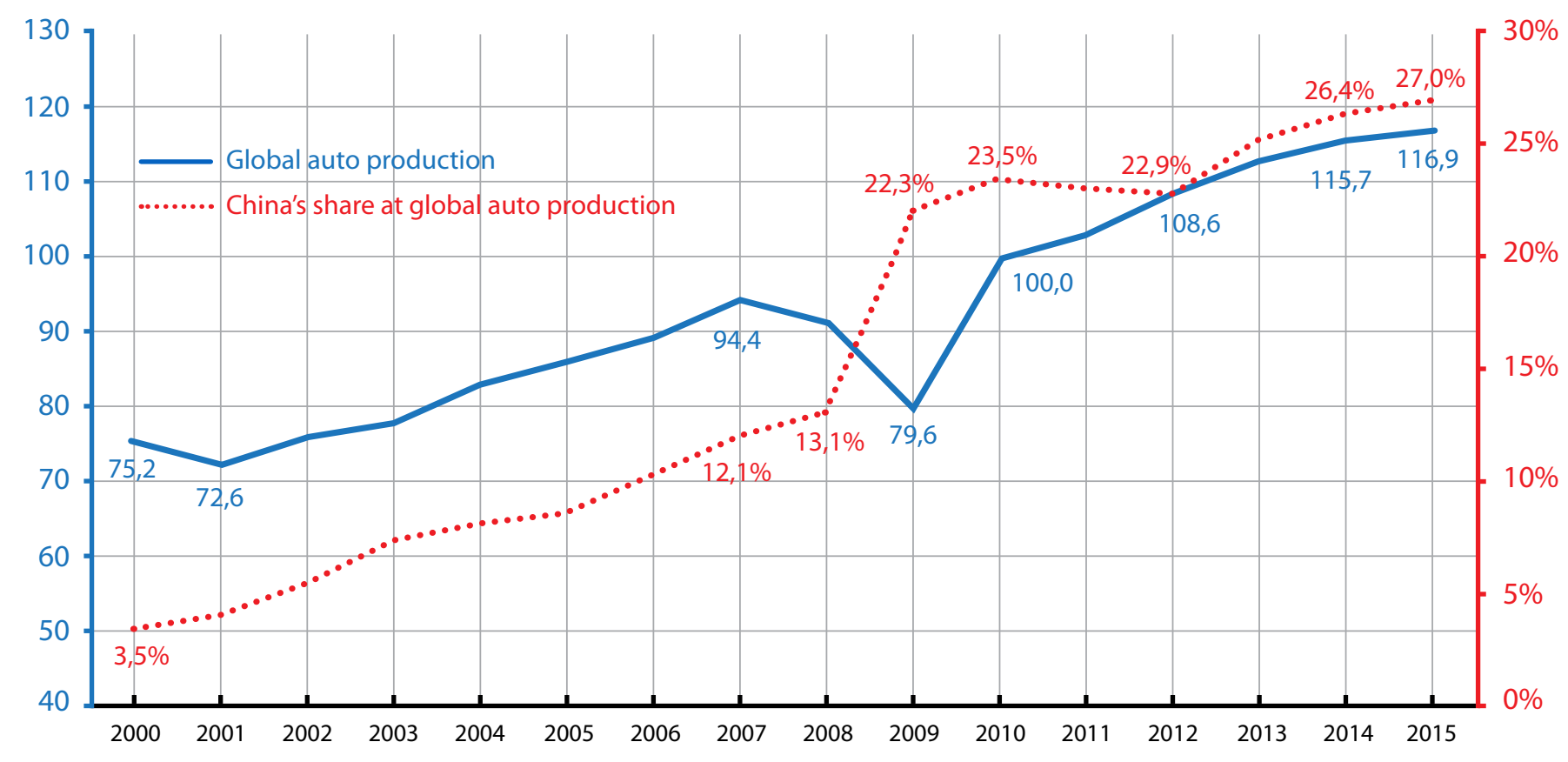

Source: OICA - Organisation Internationale des Constructeurs d'Automobiles 2016, www.oica.net. Indexing, calculation of China's share by Quest Research. Chart www.quest-trendmagazine.com 
The expectation behind such an arrangement was that Chinese automakers would acquire technology and know-how from their foreign partners, usually leading international automakers. It can also improve local supply industry with requirements of high rates of local content (the percentage of auto parts purchased from local suppliers in an assembly) (Sun, Mellahi, and Thun, 2010). In exchange, foreign partners would gain access to the vast Chinese car market. Such opportunities were greatly welcomed by international automakers as the passenger car markets in the industrialized market were approaching saturation during that time (Chang, 2016). In addition, the Chinese government believed that the 50-50 JV arrangement would also prevent foreign automakers from dominating the Chinese market. Even today, establishing a wholly foreign-owned automobile enterprise in China is prohibited (Chang, 2016). Consequently, firms such as Volkswagen, Citroën, General Motors, and Ford all partnered with domestic automakers. By the end of 1997, China had about 500 FDl-involved automobile firms; among these, 80 were assembly JVs and 410 were auto parts JVs (Sit and Liu, 2000).

It is evident that during this early development stage, the Chinese government adopted the grabbing hand model. For instance,"in 1988, the government proposed a strategy of supporting 'three majors and three minors' with First Automobile Works (FAW), Second Automobile Works (SAW), and Shanghai Automotive Industry Corporation (SAIC) named as the three majors, and Beijing, Tianjin, and Guangzhou firms as the three minors - to limit the total number of firms, and provide a high degree of protection." (Chu, 2011: 1243). In addition, once the Shanghai Volkswagen Automotive Corporation (SVW) was formed, the Shanghai government listed it as a "pillar firm" in its development plan and provided preferential treatment in taxation, foreign loans, exchange rates, and materials procurement (Frynas, Mellahi, and Pigman, 2006).

In addition, the government imposed coercive pressure on Chinese and foreign automakers to jumpstart the national automobile industry by imposing the 50-50 $\mathrm{J}$ arrangement and banning foreign-owned automobile enterprises in China. Despite the good intention, JV partnerships are structured in a way that the Chinese firm is mainly responsible for auto assembly operations and the foreign partner is in charge of new car designs and branding (Chang, 2016). In addition, Chinese automakers did not form exclusive relationships with their foreign partners. For example, SAIC had formed multiple joint ventures, including Shanghai-Volkswagen, ShanghaiGeneral Motors, among others. Due to the nature of such non-exclusive partnerships and to the concerns about the country's inadequate enforcement and enactment of intellectual property protection, foreign automakers were reluctant to share their full knowledge with their Chinese partners (Guo et al., 2014; Roberto et al., 2011).

Furthermore, hierarchical control rather than market relations determined the choices of suppliers. For example, the Shanghai government formed a localization office, which charged local suppliers' products, financing, technology adopted or imported. And the localization office requested SWW to source from these firms (Sun et al., 2010). Further, high tariffs and entry restrictions enabled the JVs to price cars high and obtain high profits (Chu, 2011). Although such a strong grabbing hand allowed rapid development of the Chinese automakers and enabled them to acquire manufacturing capabilities in a relatively short period of time, they have not gained full access to closely guarded cutting-edge technologies and R\&D.

In short, during the period of early development, the Chinese government's strong grabbing hand, on the one hand, allowed the weak Chinese automakers to pursue CE transformation through corporate venturing by entering the 50-50 JV arrangement with their foreign partners. On the other hand, a high level of regulative pressure and the nature of the JV arrangement also constrained Chinese automakers' ability to develop marketing capabilities as well as new product development and independent innovation capabilities.

\section{Rapid Development Stage (Late 1990s to 2005)}

Starting in the late 1990s, the institutional environment in China experienced rapid and significant changes. Three changes relevant to the automobile industry development were the increasing power of industry ministries and local (e.g., provincial) governments due to the gradual removal of central planning mechanisms (Guo et al., 2014), China's entry into the World Trade Organization (WTO) in 2001, and the rising household income along with improved road and highway infrastructure in China. Previously auto consumers were mainly institutions and taxi companies. However, the increase of individual wealth fostered a segment with price-sensitive consumers. Private auto ownership increased around 22 percent annually from 1996 to 2005 (Chu, 2011).

10 NEW ENGLAND JOURNAL OF ENTREPRENEURSHIP 
The more powerful industry ministries and local governments gave birth to large automobile conglomerates such as FAW and SAIC (Sit and Liu, 2000) as well as local government-owned automakers such as Chery Auto. Today there are a number of regional auto manufacturing hubs in northern China, the central coast around Shanghai, southern China, and western China (Chang, 2016). Although these local governments provided strong support, which has been crucial to the success of JVs with operations in their region, they made it difficult for $\mathrm{JV}$ to be successful in other regional markets (Chang, 2016). For instance, in Shanghai, one will find more cars manufactured by SAIC's joint ventures with GM and Volkswagen, but many fewer cars by Ford or Toyota whose JV operations are in northern and southwestern China (Chang, 2016). In addition, the Shanghai municipal government required that city taxis be the Santana model from SVW. In 1996, the Shanghai government banned cars with engine capacity lower than 1.6 liters to exclude Xiali cars (produced in Tianjin). In 1998, it levied an extra $\$ 10,000$ license fees on Citroën cars (ZX) Fukang) made in Hubei province, and a lower license tax to Santana buyers (Sun et al., 2010).

Second, the growth rate of the Chinese auto industry accelerated rapidly after the country's entry into the WTO in 2001, which encouraged more foreign automakers in the country (Roberto et al., 2011) and exposed domestic automakers to fierce competition (Guo et al., 2014). Lastly, rapid national economic growth, rising household incomes, and the development of the highway and road infrastructure throughout China also fueled consumer demand for automobiles and fierce development of the Chinese automobile industry. In 2009, China produced 10.38 million passenger cars, surpassing the United States as the world's largest manufacturer. The rising domestic demand also gave birth to several independent automakers. These newcomers to the industry and are not state-owned enterprises. The most well-known independent automakers in China are BYD Auto and Geely Auto.

Industry growth has been driven by rising domestic demand and encouraged by supportive government policies. During the global financial crisis of 2008-2009, the Chinese government implemented generous incentives to drive growth in the Chinese market. The stimulus package initially applied only to small car models of engines below 1.6 liters, but later in 2010 was expanded to include all passenger cars. Incentives by the central government effectively encouraged auto purchases despite the global economic downturn
(Roberto et al., 2011). And, auto distribution networks were established hierarchically. For example, SWW vehicles flowed from manufacturers to regional, provincial, municipal sales agents, and then to retailers.

During the rapid development period, we believe the Chinese government scaled back its regulative influence and adopted the helping hand model, encouraging Chinese auto firms to further their CE initiatives especially through continuous strategy renewal. The Chinese government did not exert strong coercive pressure on auto firms but was actively involved in improving overall road construction and highway infrastructure as well as providing economic incentives to ensure auto purchases during the global financial crisis. Government at the central and the local levels also provided key support for Chinese automakers' strategic renewal. For example, in our recent case study of Chang'an (Guo, et al., 2014), one of China's leading automakers, we found that Chang'an was able to engage in a series of strategic renewal activities by participating in national technology development projects and by applying for national innovation funds for improving R\&D capabilities (e.g., upgrading R\&D facilities and equipment), developing new products (e.g., providing more financial support for lab experiments), and conducting new technology research (e.g., providing more financial support for international collaboration). Compared with the grabbing hand model, we consider the helping hand model effective during the rapid industry growth stage as most automakers during this period acquired state-of-the-art manufacturing capabilities from their foreign partners and were able to manufacture their own brands and those of their foreign partners. Most Chinese automakers were in the process of exploiting the existing and identifying new sources of competitive advantages to face the fierce competition especially after China's entry into WTO. However, as discussed earlier, the involvement of local government in protecting the leading regional automakers has created a scattered and fragmented Chinese auto industry.

\section{Recent Transformation Stage (2006-Present)}

The year 2006 marks the beginning of the new industry growth stage, which we term "recent transformation." In the 11th Five Year Plan (FYP) (2006-2010), the government for the first time used the term "indigenous brands" and called for auto production capacity of at least 2 million vehicles - 50 percent from manufacturing indigenous brands and only 10 percent would be exported (Chang, 
2016). It is also evident in the 11th FYP that Chinese automakers would not be judged on their ability to develop Chinese intellectual property that would relieve reliance on foreign technology (Chang, 2016).

Indeed, high oil prices, air pollution, and China's commitment to reduce carbon emissions have led the government to prioritize development of the energy vehicle industry. Lawmakers have introduced policies and incentives to support development of new energy vehicles (NEVs) including electric (hybrid, plug-in, and battery), fuel cell, and hydrogen powered (APCO Worldwide Report). In 2009, the Chinese government initiated pilot programs in 13 cities (later expanded to 20 cities) for NEVs used for public service purposes such as public transition, taxis, and official business. The programs provided subsidies for public transportation (e.g., USD 62,969 for hybrid buses) and to support the purchase of NEVs, translating into a price reduction for consumers. In addition, from 2010 to 2020, the central government plans to allocate more than USD 15 billion to support (1) R\&D and industrialization of energy-efficient and new energy cars; (2) development of NEV pilot projects; (3) promotion of hybrid electric vehicles and other energy-saving cars; (4) development of key components; and (5) development of electric vehicle infrastructures in the pilot cities. It projected that three to five key automakers will emerge with their combined market share exceeding 60 percent. The plan also predicts 5 million NEVs will be produced, enabling China to become the leading producer of NEVs by 2020 (APCO Worldwide Report).

In addition to NEVs, the Chinese government has also been heavily promoting vehicle connectivity (e.g., between driver and vehicle, vehicles and transportation systems, Internet, mobile networks, and satellites) (Chang, 2016). The Internet-enabled car industry was identified by the government as a new opportunity for domestic automakers to become leaders in the new industry and again reduce their reliance on foreign technology. As a result, most of China's leading automakers have announced investments in Internet-enabled cars.

The government continues to adopt the helping hand model and provides various incentives to promote NEVs, including direct subsidies to automakers that produce NEVs, subsidies to local government who purchases green fleets, and tax breaks and free registration for consumers (Chang, 2016). In fact, since the 2009 Automotive Industry Readjustment and Revitalization Plan, the government did not announce a sector-specific policy, an indicator that the government is generally satisfied with the auto industry's growth (Chang, 2016). As discussed earlier, government's attention has shifted to specific areas of the auto industry and has made these its top priorities. Nevertheless, the government did exert normative pressure on Chinese auto firms and shaped cognitive understanding of the importance of cultivating independent innovation and new product development capabilities for Chinese automakers to gain leading positions and reduce reliance on foreign technologies in new areas such as NEVs and Internet-enabled cars.

Following these government initiatives, Chinese auto firms, for example, Chang'an in our recent case study (Guo et al., 2014), identified building an independent innovation system as an important entrepreneurial endeavor. The innovation systems were built to develop core technologies, reconfigure available resources, and eventually new products -important CE transformation through innovation and continuous strategic renewal. To support these CE initiatives, most leading Chinese auto firms also engaged in organizational rejuvenation activities by cultivating strong, innovation-supportive corporate cultures and establishing a compatible human resources management (HRM) system.

\section{Implications and Conclusion}

Our analysis based on the case study of the Chinese auto firms and auto industry's transformation has answered two research questions raised at the beginning of this editorial: (1) what roles can governments play in enabling and stimulating firms' CE in emerging economies and (2) what is the impact of government involvement on important CE outcomes, namely EMFs' innovation, strategic renewal, and corporate venturing? It is evident in our analysis that the Chinese government played different roles at different stages. During the initiation stage, government adopted a strong grabbing hand to jumpstart the auto industry and initiated domestic automakers' $\mathrm{CE}$ transformation through corporate venturing by forcing the 50-50 JV partnership arrangement between Chinese and foreign automakers. The impact of the grabbling hand model was demonstrated in the Chinese automakers' improved manufacturing capabilities but it also constrained their ability to acquire core technologies as well as marketing and R\&D capabilities, all of which are crucial for innovation and NPD. During the rapid development and recent transformation periods, the government adopted a

12 NEW ENGLAND JOURNAL OF ENTREPRENEURSHIP 
helping hand model to provide favorable economic incentives, policies, as well as improve the overall infrastructure and FDI investment environment to promote Chinese automakers' $C$ E transformation through strategic renewal and innovation in NEVs and Internet-enabled cars. The helping hand was also effective in establishing industry norms based on government expectations and in creating a value system to favor development of NEVs and Internet-enabled cars.

In the Western CE literature, for instance, Dess et al. (2003), stress the different CE roles of management at multiple levels of the organization and emphasize the role of top management leadership in CE. We suggest that the argument can be extended to examine the different roles of governments in initiating, enabling, and shaping the CE transformation of firms in emerging economies. It is evident that governments can serve an important function in assisting and guiding top managers of EMFs in identifying entrepreneurial opportunities, suggesting innovative ideas and initiatives, offering financial and political support for exploiting opportunities identified by CE programs, supporting investment in building the EMFs' capabilities and sustained competitive advantages. We believe the unique institutional compositions of the emerging markets may require different research topics that are currently underexamined in the mainstream CE literature. To achieve this goal and to develop a better understanding of CE-related issues, especially those pertinent in emerging markets, we encourage all interested scholars to submit relevant scholarly work to our special issue on "Corporate Entrepreneurship in Emerging Markets." After all, we need to address the critical questions of how emerging markets are reshaping globalization.

\section{REFERENCES}

APCO Worldwide Report. (November, 2010). Market analysis report: China's automotive industry. Retrieved on March 8, 2012, from http://www.export.gov.il/uploadfiles/03_2012/chinasautomotiveindustry.pdf

Busenitz, L.W., Gomez, C., and Spencer, J.W. (2000). Country institutional profiles: Unlocking entrepreneurial phenomena. Academy of Management Journal, 43: 994-1003.

Chang, C. (2016). China's 13th five-year plan: Implications for the automobile industry. Retrieved on April 10, 2017, from https://www.uscc.gov/sites/default/files/Crystal\%20Chang_Written\%20Testimony\%20042716.pdf

Chu, W. (2011). How the Chinese government promoted a global automobile industry? Industrial and Corporate Change, 20(5): 1235-1276.

Covin, J.G., and Miles, M.P. (1999). Corporate entrepreneurship and the pursuit of competitive advantage. Entrepreneurship Theory and Practice, 23: 47-63.

Covin, J.G. and Slevin, D.P. (1991). A conceptual model of entrepreneurship as a firm behavior. Entrepreneurship Theory and Practice, 16(1): 7-24.

Dess, G. G., Ireland, R. D., Zahra, S. A., Floyd, S. W., Janney, J. J., and Lane, P. J. (2003). Emerging issues in corporate entrepreneurship, Journal of Management, 29(3): 351-378.

DiMaggio, P. and Powell, W. (1983). The iron cage revisited: Institutional isomorphism and collective rationality in organizational fields. American Sociological Review, 48(2): 147-160.

Eisenhardt, K. (1989). Building theories from case study research. Academy of Management Review, 14(4): $532-550$.

Frye, T., and Shleifer, A. 1997. The invisible hand and the grabbing hand. American Economic Review, 87(2): 354-358.

Frynas, J., Mellahi, K., and Pigman, G. (2006). First mover advantages in international business and firm-specific political resources. Strategic Management Journal, 27: 321-345. 
Guo, C., Jiang, C., and Yang, Q. (2014). The development of organizational capabilities and corporate entrepreneurial processes: The case of Chinese automobile firms. Thunderbird International Business Review, 56(6): 483-500.

Guth, W.D., and Ginserg, A. (1990). Guest editor's introduction: Corporate entrepreneurship. Strategic Management Journal, 11(5): 5-15.

Hayton, J. C., George, G., and Zahra, S. A. (2002). National culture and entrepreneurship: A review of behavioral research. Entrepreneurship Theory and Practice, 26(4): 33-52.

Jiang, C. X., Yang, Q., Li, S., Wang, Y. (2011). The moderating effect of foreign direct investment intensity on local firms'intangible resources investment and performance implications. Journal of International Management, 17(4): 291-302.

Jiang, C., Yang, Q., Song, S., Annavarjula, M. (2016). Emerging market firms' catch-up strategy in new product development: Cases from Chinese companies. International Journal of Business and Emerging Markets, 8(3): 324-339.

Kostova, T. (1997). Country institutional profiles: Concepts and measurement. Academy of Management Proceedings, 1: $180-184$.

Kotabe, M., Jiang, C., Murray, J. (2017). Examining complementary effects of political networking capability with absorptive capacity on EMFs' innovative performance. Journal of Management, 43(4): 1131-1156.

Li, J. and Kozhikode, R. (2008). Knowledge management and innovation strategy: The challenge for latecomers in emerging economies. Asia Pacific Journal of Management, 25(3): 429-450.

Luo, Y. 2000. How to Enter China: Choices and Lessons. Ann Arbor: University of Michigan Press.

Mahmood, I. P., and Rufin, C. (2005). Government's dilemma: The role of government in imitation and innovation. Academy of Management Review, 30: 338-360.

Mathews, J. A. (2006). Dragon multinationals: new players in the 21st century globalization. Asia Pacific Journal of Management, 23(1): 5-27

Minniti, M. (2008). The role of government policy on entrepreneurial activity: Productive, unproductive, or destructive? Entrepreneurship theory and Practice, 32(5): 779-790.

Peng, M.W. (2003). Institutional transitions and strategic choices. Academy of Management Review, 28(2), 275-286.

Phan, P. H., Wright, M., Ucbasaran, D., and Tan, W-L (2009). Corporate entrepreneurship: Current research and future directions. Journal of Business Venturing, 24(3): 197-205.

Quest Trend Magazine. Global auto production since 2008: Without China stagnation. Retrieved from http://www.questtrendmagazine.com/en/automobile-industry/china/market-share-of-china-at-global-automobile-production.html.

Roberto, M., Guo, C., and Jiang, C. X. (2011). Chang'an automobile and the Chinese automotive industry and teaching notes. Emerald Emerging Markets Case Studies, 1(4): 1-17.

Sit, V.F.S., and Liu, W. (2000). Restructuring and spatial change of China's auto industry under institutional reform and globalization. Annals of the Association of American Geographers, 90(4): 653-673.

Shleifer, A., and Vishny, R. W. (2002). The Grabbing Hand: Government Pathologies and Their Cures. Harvard University Press.

Sturgeon, T. J., and Van Biesebroeck, J. (2010). Effects of the crisis on the automotive industry in developing countries: A global value chain perspective. Policy Research Working Paper 5330, World Bank.

Sun, P., Mellahi, K., and Thun, E. (2010). The dynamic value of MNE political embeddedness: The case of the Chinese automobile industry. Journal of International Business Studies, 41: 1161-1182.

14 NEW ENGLAND JOURNAL OF ENTREPRENEURSHIP 
Tan, J. (2007). Phase transitions and emergence of entrepreneurship: The transformation of Chinese SOEs over time. Journal of Business Venturing, 22: 77-96.

Von Hippel, E. (1977). Successful and failing internal corporate ventures: An empirical analysis. Industrial Marketing Management, 6(3): 163-174.

Wang, J.H., Hong, Kafourors, M., and Wright, M. (2012). Exploring the role of government involvement in outward FDI from emerging economies. Journal of International Business Studies, 43(7): 655-676.

Yin, R. (1994). Case Study Research: Design and Methods (2nd ed.). Thousand Oaks, CA: Sage Publishing.

Yiu, D. W., Lau, C. M. and Bruton, G. D. (2007). International venturing by emerging economy firms: The effects of firm capabilities, home country networks, and corporate entrepreneurship. Journal of International Business Studies, 38(4): 519-540.

Yiu, D. and Lau, C.M. (2008). Corporate entrepreneurship as resource capital configuration in emerging market firms. Entrepreneurship Theory \& Practice, 32: 37-58.

Zahra, S.A. (1995). Corporate entrepreneurship and financial performance: The case of management leveraged buyouts. Journal of Business Venturing, 10(3): 225-247.

Zahra, S.A. (1996). Governance, ownership, and corporate entrepreneurship: The moderating impact of industry technological opportunities. Academy of Management Journal, 39(6): 1713-1735.

Zahra, S.A., Ireland, R.D., Gutierrez, I., and Hitt, M.A. (2000). International expansion by new venture firms: International diversity, mode of market entry, technological learning, and performance. Academy of Management Journal, 43: 926-950.

Zahra, S.A., and George, G. (2002). Absorptive capacity: A review, reconceptualization and extension. Academy of Management Review, 27(2): 213-240. 


\section{ABOUT THE AUTHORS}

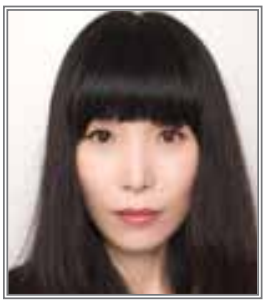

Dr. Grace Chun Guo (Chun-guog@sacredheart.edu) is an Associate Professor of Management at Jack Welch College of Business, Sacred Heart University. Dr. Guo earned her Ph.D. in Organization Studies from the University of Massachusetts Amherst. She is the Editor-in-Chief of the New England Journal of Entrepreneurship. Her major research interests include entrepreneurial processes and corporate entrepreneurship in emerging markets, international migrant employee management, global career management, management of international migrant employees, Chinese management, and organizational justice. Dr. Guo's academic work has appeared in journals and books, such as Management and Organization Review, International Business Review, International Journal of Human Resource Management, Journal of Managerial Psychology, Career Development International, Thunderbird International Business Review, International Entrepreneurship and Management Journal, and The Oxford Handbook of Recruitment.

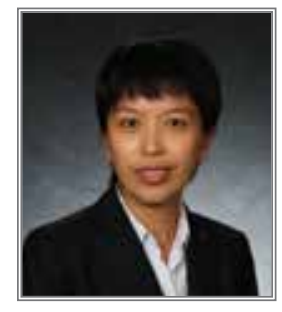

Dr. Crystal X. Jiang (cjiang1@bryant.edu) holds a Ph.D. from Temple University in International Business Management and Strategic Management. She is an Associate Editor of the New England Journal of Entrepreneurship. Dr. Jiang's primary research focus on firms originated from emerging economies in political networking, capability building, and innovation strategy, among others. She has published with the top-tier journals in the field such as the Journal of Management (JOM), Journal of International Business Studies (JIBS), Journal of International Management (JIM), Journal of World Business (JWB), Asia Pacific Journal of Management (APJM), Handbook of International Business, and Thunderbird International Business Review.

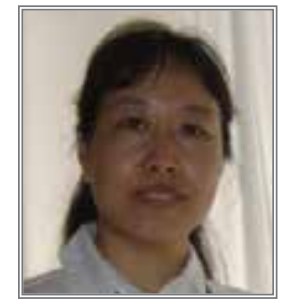

Dr. Qin Yang (yang@rmu.edu) is a full professor in the Management Department, School of Business at Robert Morris University. She received her Ph.D. in Strategic Management from Fox School of Business, Temple University. Dr. Yang is a member of the New England Journal of Entrepreneurship Reviewer Panel. Her current research interests target on knowledge management, strategies in multinational corporations, entrepreneurship in emerging markets, and strategic leadership. She has published in the Asia Pacific Journal of Management, Journal of Management, Journal of International Management, Journal of Small Business Management, and others. 